\title{
The ecophysiology of under-ice fauna
}

\author{
ARNE V. AARSET
}

\begin{abstract}
Aarset, A. V. 1991: The ecophysiology of under-ice fauna. Pp. 309-324 in Sakshaug, E., Hopkins, C.C.E. \& Øritsland, N.A. (eds.): Proceedings of the Pro Mare Symposium on Polar Marine Ecology, Trondheim. 12-16 May 1990. Polar Research 10(I).

During exposure to low salinity, the under-ice amphipods Gammarus wilkitzkii and Onisimus glacialis appeared as euryhaline osmoregulators, displaying regulation of haemolymph concentrations of sodium and chloride. Free amino acids took part in the regulation. During freezing and brine formation, the amphipods were freeze-sensitive and did not tolerate being frozen into solid ice. However, they could stay in the vicinity of the ice, conforming osmotically to the ambient brine and thus lowering the melting point of the amphipods' body fluids. This prevented internal ice formation in the absence of antifreeze agents (THF) in the haemolymph. When $G$. wilkitzkii, $O$. glacialis and Apherusa glacialis were exposed to dilute seawater, elevated rates of oxygen consumption and ammonia excretion were observed. The $\mathrm{O}: \mathrm{N}$ atomic ratio was kept nearly constant during hyposmotic stress, indicating protein/lipids as metabolic substratc. Rates of oxygen consumption and ammonia excretion increased with increasing osmotic differences between the haemolymph and the medium, indicating higher energy requirements for osmotic and ionic regulation at low salinities. A minor decrease in haemolymph sodium concentrations coincided with the increased ammonia output during hyposmotic stress, indicating a possible counter ion regulation of $\mathrm{NH}_{4}^{+}$and $\mathrm{Na}^{+}$. An increased rate of oxygen consumption, ammonia excretion and $\mathrm{O}: \mathrm{N}$ ratio versus temperature was observed for all species.
\end{abstract}

Arne V. Aarset*, Department of Zoology, University of Trondheim, N-7055 Draguoll, Norway.

\section{Introduction}

Polar sea ice is a habitat for under-ice biota (Horner 1985). If these organisms are associated with the sea ice throughout the year, they will be exposed to seasonal changes in physical parameters as the ice melts or freezes. It is clear that animals in intimate contact with the ice would benefit considerably from physiological and behavioural adaptations that permit them to survive freezing and thawing changes in their immediate environment.

Sea-ice initially forms when open water is exposed to cold air. At the ice/water interface of growing ice, salts are included as brine pockets in the ice (Weeks 1968). In response to temperature change and internal stress, the pockets interconnect as brine channels, and about 50-300 channels per $\mathrm{m}^{2}$ may exist along the bottom of the ice (Lake \& Lewis 1970; Eide \& Martin 1975; Niddrauer \& Martin 1979). As the Arctic sea ice becomes thicker, the average bulk salinity of the ice decreases from $10-20 \%$ to about $4-8 \%$, indicating a major loss of brine to the ocean (Malmgren 1927; Cox \& Weeks 1974). However, the volume and salinity of brine excluded from sea

\footnotetext{
"Present address: Centre for Environment and Development. University of Trodheim, N-7055 Trondheim. Norway.
}

ice depend on the growth rate of the ice and the salinity of the seawater (Wakatsuchi \& Ono 1983). In the Arctic, melting of the sea-ice surface begins as air temperatures approach freezing point with a development of melt ponds at the surface of the ice floes (Nansen 1906). A large part of this meltwater flows further off the ice and into the sea. Melt ponds which are characteristic of melting ice in the Arctic have rarely been seen in the Antarctic (Gordon 1981; Maykut 1985) as Antarctic pack ice melts predominantly at the ice/water interface (Andreas \& Ackley 1982).

In both polar regions the true under-ice (sympagic) fauna is dominated by amphipods (Carey 1985). The dominant species in the ice community of the Arctic Barents Sea are Apherusa glacialis, Gammarus wilkitzkii and Onisimus glacialis (Gulliksen 1984; Gulliksen \& Lønne 1989; Aarset \& Aaunaas 1987a). In the Antarctic Weddell Sea, the dominant species observed in the ice community were the amphipod Eusirus antarcticus and the first juvenile stage of the krill Euphausia superba (Aarset \& Torres 1989). The microdistribution of these crustaceans in the under-ice habitats varies from species to species (Carey 1985). Individuals have been observed living in brine channels (Cross 1982; Newbury 1983) and 
partially or fully embedded in the ice (Gulliksen 1984), Green \& Steele (1975) reported that Gammaraconthus loricatus was the only amphipod species associated with ice stalactites and may at times be frozen within them. In the Weddell Sea, $E$. antarcticus was found living in brine channels or at the ice/water interface and the first juvenile stage of the krill $E$. superba was observed feeding on ice algae (Aarset 1988).

During summer melt of the sea ice, the crustaceans are likely to encounter low salinity conditions, and during sea-ice growth they will be exposed to low temperature and high salinity brine at the ice/water interface. The mechanisms of cold resistance and osmotic regulation of the animals will ultimately determine whether they must leave the sea ice or may stay and cope physiologically with the changing conditions. This topic was the first to be examined at the start of the Pro Mare program. The next question to be answered was, What would be the metabolic consequence of an adaptation of amphipods to the sea-ice environment? We have in our studies therefore recorded the metabolic responses (measured as the specific oxygen consumption and ammonia excretion) of the Arctic amphipods exposed to various seawater salinities and temperatures (Aarset \& Aunaas 1990a, b, c, 1992).

The effects of salinity and temperature on the rates of oxygen consumption of crustacean species in general have been well documented (Kinne 1970, 1971: Ivleva 1980; Vernberg 1983). Similarly, the effects of salinity and temperature on the rates of ammonia excretion have been presented for several crustacean species (Needham 1957; Haberfield et al. 1975; Mangum et al. 1976; Spaargaren et al. 1982; Claybrook 1983; Quarmby 1985; Taylor et al. 1987). Some authors have further been focusing on the influence of environmental parameters on the relationship between consumed oxygen and excreted nitrogen (atomic $\mathrm{O}: \mathrm{N}$ ratio), to obtain an indication of the kind of substrate oxidised by the animals (Mayzaud \& Conover 1988 for ref.). A substrate of only proteins should give a minimum value of 7 (Mayzaud 1973), with equivalent weights of proteins and lipids a ratio of 24 is obtained and if lipids and carbohydrates are metabolised, the ratio would approach infinity (Conover \& Corner 1968). Our estimates of the $O: N$ ratio were used to clarify the nature of the metabolic substrates oxidised in order to meet the energetic requirements during salinity and temperature stress.
Studies of similar adaptation mechanisms of Antarctic under-ice crustaceans (Aarset 1988; Aarset \& Torres 1989) as well as Arctic intertidal amphipods (Aarset \& Zachariassen 1988) have been included in the Pro Mare programme to compare the physiological mechanisms involved in the adaptation of amphipods to the under-ice habitat of the Barents Sea.

\section{Osmotic regulation}

Arctic sympagic amphipod species appear to be euryhaline organisms (Aarset \& Aunaas 1987a). The adaptation of such animals to changes in seawater salinity is based on two different types of physiological mechanisms: the anisosmotic regulation of inorganic ions between blood and the external medium, and the intracellular isosmotic regulation, or cell volume regulation of free amino acids (Gilles 1979; Gilles \& Pequeux 1983; Clarke 1985)

\section{Inorganic ions}

In the Arctic, G. wilkitzkii and $O$. glacialis occur on the undersurface and in interstices of the sea ice where they might be exposed to low salinity seawater during sea-ice melting. In such an environment, the sympagic amphipods would face the problem of diffuse loss of solutes and osmotic influx of water. To cope with these problems, the animals may lower their body fluid concentrations, thus reducing diffusion gradients and/or the ion-water permeabilities of the body surfaces, as well as eliminating water through the production of urine (Potts 1955; Shaw \& Sutcliff 1961; Werntz 1963; Lockwood et al 1973; Kirschner 1979; Mantel \& Farmer 1983).

The sympagic amphipod species $G$. wilkitzkii and $O$. glacialis appeared as hyperosmotic regulators (Fig. 1A), both displaying extracellular regulation of haemolymph concentrations of sodium and chloride (Fig. 1B and C) (Aarset \& Aunaas 1987a). The haemolymph concentration of the poorer regulator $G$. wilkitzkii was nearly parallel with the isosmotic line in media below a salinity of about $17 \mathrm{ppt}$ (Fig. 1A). This response might be of adaptive value for marine organisms inhabiting water which is brackish, due to the reduction in the ionic concentration gradients (Potts 1955) (Fig. 1B and C). The amphipod $O$. glacialis maintained a nearly constant internal 
Fig. 1. Haemolymph osmolality (A), sodium concentrations (B) and chloride concentrations $(C)$ in the haemolymph of Gammarus wilkitzkii (-O-), Onisimus glacialis (-) and Parathemisto libellula (-D-) acclimated for 24 hours to various salinities. The data are given as Mean \pm SD with number of animals indicated above each point. The solid lines show the isosmotic (A) or iso-ionic conditions (B, C). (Aarset \& Aunaas 1987a).

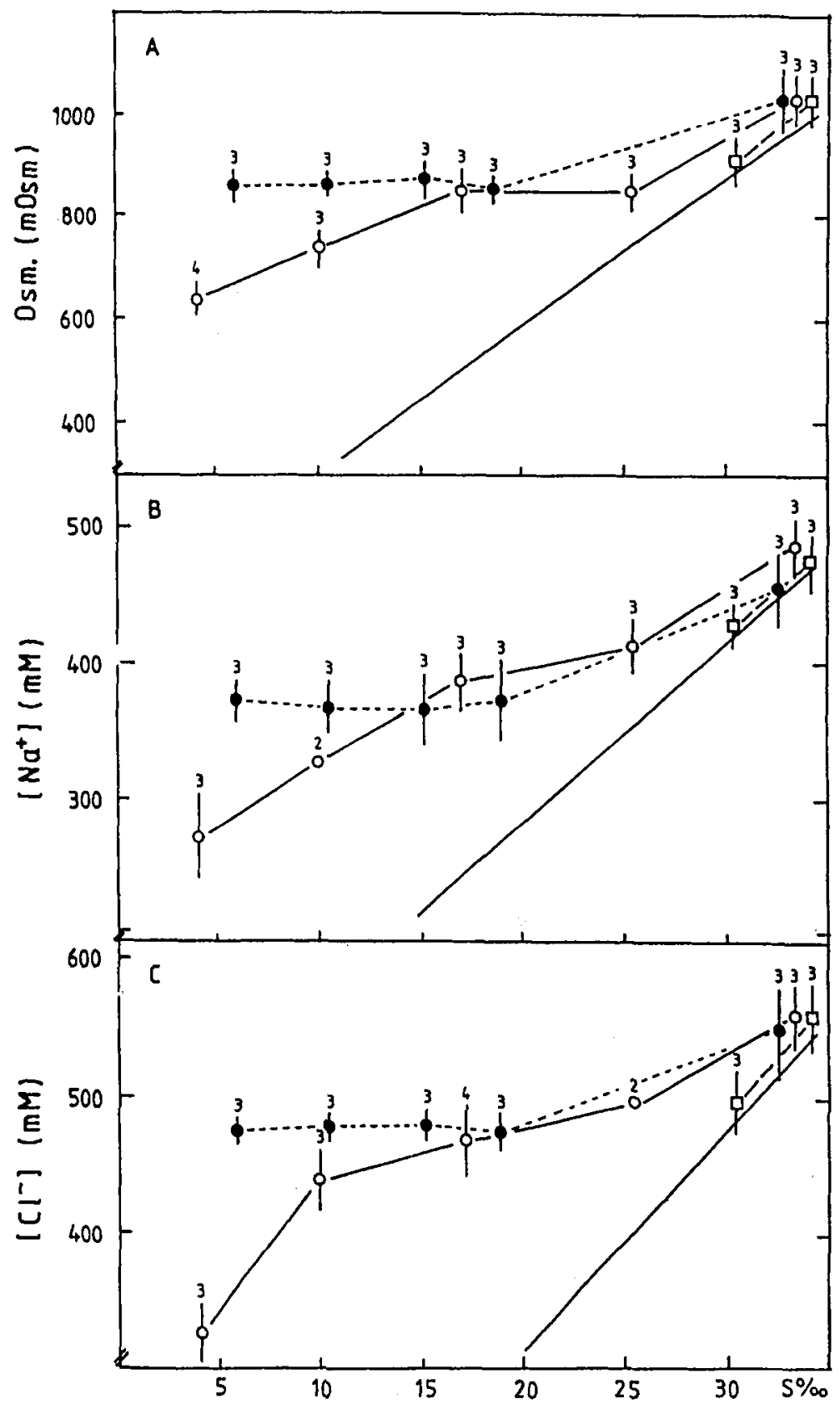

concentration of sodium and chloride over a wide range of external salinities (Fig. 1B and C), and thus appeared to be a very efficient osmotic regulator (Fig. 1A).

The amphipod $P$. libellula was a stenohaline osmoconformer with haemolymph isosmotic to the ambient seawater over the tolerated salinity range (Fig. 1A). The observed lack of a sodium and chloride regulation of the haemolymph (Fig. $1 \mathrm{~B}$ and $\mathrm{C}$ ) is characteristic of osmoconformers (Gilles 1979). Being an osmoconformer with a relatively low tolerance to salinity variations, this species is forced to live in a rather constant environment. The species $G$. wilkitzkii and $O$. 
glacialis thus have a larger capacity to adapt to an under-ice environment with salinity variations than $P$. libellula.

The Antarctic sympagic amphipod E. antarcticus and the first juvenile stage of the krill $E$. supherba appeared as osmoconformers with a low salinity tolerance (Aarset 1988), indicating that these Antarctic species are not as euryhaline as the Arctic species. This might be associated with differences in the melt progression of the two polar regions with the most significant input of meltwater to the sea surface in the Arctic, creating larger fluctuations in water salinity (Gordon 1981; Maykut 1985). The physiological response of the Antarctic species is thus similar to pelagic crustaceans, while the Arctic sympagic fauna behave more as benthic intertidal species (Werntz 1963; Kinne 1970; Dorgelo 1977; Aarset \& Zachariassen 1988).

\section{Free amino acids}

A decrease in the concentration of FAA (free amino acids) versus low salinity exposure was documented for the sympagic amphipods $G$. wilkitzkii and $O$. glacialis and has been observed for other crustacean species (Florkin \& Schoffeniels 1969; Schoffeniels 1976; Gilles 1979; Gilles \& Pequeux 1983; Clarke 1985). The adjustment of the intracellular FAA seem to be related to interaction of inorganic ions and enzyme activity in such a way that at low salinities the balance of amino acid synthesis and degradation favour a decline in the FAA pool. This is reduced by release of amino acids from the tissues. A rather high tissue/haemolymph FAA ratio in crustaceans reflects the importance of the amino acids in addition to the inorganic ions as intracellular osmotic effectors (Gilles 1979; Gillles \& Pequeux 1983; Clarke 1985).

In the amphipod $G$, wilkitzkii, a $50 \%$ reduction in the total concentration of free amino acids (TFAA) present at $35 \% c$ occurred during exposure to $5 \%$ salinity (Aarset et al. unpubl. data) (Fig 2). The decrease in TFAA corresponds to a decline in haemolymph osmolality and inorganic ions concentrations (Aarset \& Aunaas 1987a), indicating an osmotic response of the amphipod cells. A reduction in the total concentration of essential amino acids (EAA) was also present due mainly to the changes in the concentration of arginine (Figs. 2 and 3 ). Arginine is an important component of the phosphagen

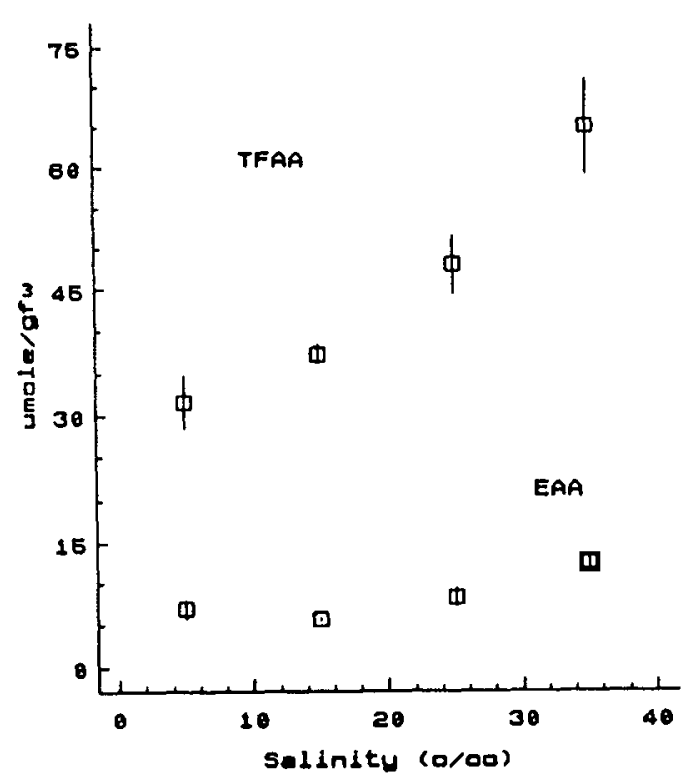

Fig. 2. Concentrations ( $\mu$ moles/g fresh weight) of total free amino acids (TFAA) and total essential amino acids (EAA) in Gammarus wilkitzkii acclimated for 24 hours to various salinities. The data are given as Mean \pm SE (Aarset et al. unpubl. data).

phosphoarginine in the crustacean muscle and appears sometimes in rather high concentrations (Gilles 1979; Claybrook 1983).

The nonessential amino acids in G. wilkitzkii accounted for more than $80 \%$ of the TFAA reduction and do so in most crustaceans (Claybrook 1983; Aarset et al. unpubl. data). Of these glycine, alanine and proline appeared to be the most important osmolytes as well as taurine (Fig. 3 ). Taurine is an end product of sulfur amino acid metabolism and like the free amino acids concentrated intracellularly (Allen \& Garrett 1971; Huxtable \& Barbeau 1976; Gilles 1979). In $G$. wilkitzkii, taurine was a most significant osmololyte in the salinity range of 35 to $15 \%$. However, Dalla Via (1986) and MeCoid et al. (1984) both demonstrated a minor contribution of taurine as osmoeffector during hyposmotic stress of the shrimp $P$. japonicus and $P$. vanname $i$, respectively. Taurine appears therefore not to have the same role as osmotic effector in all crustacean species, and this role can be different in the same species depending on the salinity in the range tolerated as has been observed for $G$. wilkitzkii at 5\% (Fig. 3).

The high glycine and alanine concentrations in 
Fig. 3. Concentrations ( $\mu$ mole/ $\mathrm{g}$ fresh weight) of taurine. glycine, alanine and arginine in Gammarus witkitzkii acclimated for 24 hours to various salinities. The data are given as Mean $\pm S E$ with number of animals indicated (Aarset et al. unpubl. data).
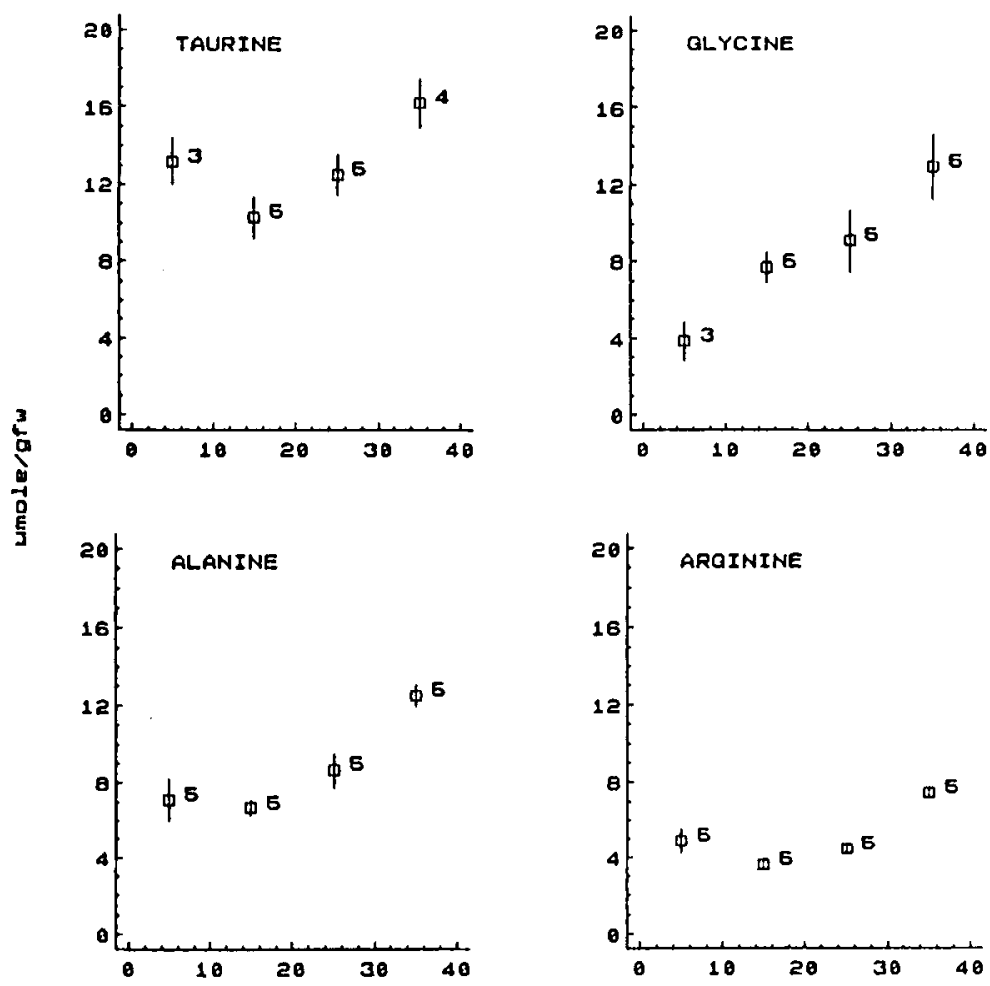

Solinity $(0 / 00)$
G. wilkitzkii decreased respectively 70 and $50 \%$ at a salinity decline from 35 to $5 \%$ (Aarset et al. unpubl. data) (Fig. 3). As loss of amino acids to the sea does not seem to be the main route in crustaceans, the observed reduction could be a result of amino acid catabolism (Claybrook 1983).

\section{Cold tolerance - brine exposure}

Ectothermic polar invertebrates and fishes have body temperatures corresponding to the ambient temperature. If the ambient temperature drops below the melting point of the body fluids, the animals face the problem of internal ice formation. To cope with this, several general strategies have been developed. Freezing tolerance is a strategy based on a tolerance to tissue ice formation, while supercooling is a strategy for avoiding freezing, thus allowing the body fluids to be cooled below the equilibrium freezing point without freezing (for previous reviews of cold tolerance see Aarset 1982; Murphy 1983; Clarke
1983; Zachariassen 1985; 1989; Storey \& Storey 1989). Polar ecotherms seem to use both these strategies.

\section{Cold hardiness}

As sea ice has a sponge-like structure with cavities, brine channels and crevices, amphipods may become trapped within the bulk sea ice as it grows and thus be exposed to low temperatures. In the Arctic, however, the sympagic amphipods $G$. wilkitzkii and $O$. glacialis did not tolerate being frozen into the solid sea ice. Instead the amphipods were able to stay away from the advancing ice front during sea ice growth (Aarset \& Aunaas 1987b). The intertidal Spitsbergen amphipod Gammarus oceanicus, however, could survive being frozen into the solid ice at a temperature of about -6 to $-7^{\circ} \mathrm{C}$ (Aarset \& Zachariassen 1988). This has also been observed for the eggs of the subarctic plaice $P$. platess $a$ (Aarset \& Jørgensen 1988).

In Antarctica, the first juvenile stage of the 
krill, E. superba, unlike the amphipod, E. antarcticus, tolerated being frozen into the solid sea ice at temperatures down to about $-4^{\circ} \mathrm{C}$ (Aarset \& Torres 1989). Although both crustaceans are mobile species, the amphipods avoided the growing ice front during freezing experiments while the krill did not. The results correlated well with underwater observations made in the Weddell Sea. During several scuba dives under the polar pack ice, underwater frazil ice formation was observed. While the krill largely disappeared during the freezing episodes, the amphipods left the congelation ice, crawled through the frazil ice layer, and took up a position at the interface of the frazil ice crystal and the surrounding seawater (Aarset 1988).

\section{Supercooling, thermal hysteresis factor (THF) and nucleating activity}

When the Arctic sympagic amphipod G. wilkitzkii were cooled in air, the amphipod froze and died at a temperature of about $-4^{\circ} \mathrm{C}$ (Table 1) (Aarset $\&$ Aunaas 1987 b). A relatively high supercooling point may indicate that some nucleating agents are present in the body fluids of the animals (Zachariassen 1980). In freeze sensitive insects, it is well known that gut content may act as an ice nucleator (Sømme 1982). In G. wilkitzkii, however, there was no observed difference in the supercooling capacity of animals with and without gut contents. Tests for extracellular nucleating agents were also negative (Table 1), indicating an intracellular nucleation. Similarly, the amphipod A. glacilis had supercooling points of about $-7^{\circ} \mathrm{C}$, and $G$. oceanicus, associated with landfast ice, about $-6.0^{\circ} \mathrm{C}$. (Aarset \& Zachariassen 1988).
When the Antarctic under-ice crustaceans $E$. antarcticus and $E$. superba were cooled in air, they froze and died at temperatures of about $-11^{\circ} \mathrm{C}$ and $-9^{\circ} \mathrm{C}$ respectively (Table 1 ) (Aarset \& Torres 1989). These relatively low supercooling points indicate that no potent nucleators were present in the body fluids of the animals, and that the Antarctic under-ice fauna appeared to have a greater supercooling capacity than the Arctic species.

Rakusa-Suszczewski \& McWhinnie (1976) studied the supercooling capacity of benthic and pelagic Antarctic species supercooled in filtered seawater. The supercooling capacity was in the range of $-4^{\circ} \mathrm{C}$ to $-8^{\circ} \mathrm{C}$ and ice formation started on gill surfaces and appendages of the animals. Our experiments with individuals supercooled in filtered seawater yielded similar results (range $-3^{\circ} \mathrm{C}$ to $-6^{\circ} \mathrm{C}$ ) (Aarset \& Torres 1989). However, as the individuals can be supercooled to a lower temperature in air, representing internal ice nucleation, it is probable that ice nucleation initiated in filtered seawater at a higher temperature originates in the medium. The survival of the under-ice fauna in a supercooled state could depend on thermal hysteresis agents present in their body fluids. These are proteinaceous compounds which act to stabilise the supercooled state and which have been demonstrated to be present in different categories of supercooled animals (DeVries 1971; Zachariassen \& Husby 1982; Denstad et al. 1987). However, several tests for thermal hysteresis agents in both Arctic and Antarctic crustaceans were all negative (Table 1.) (Aarset \& Aunaas 1987b; Aarset \& Zachariassen 1988; Aarset \& Torres 1989). The fact that animals cooled in freezing seawater were injured at a

Table 1 . Thermal data $\left({ }^{\circ} \mathrm{C}\right)$ of under $-\mathrm{jce}$ organisms. $\mathrm{SCP}=$ supercooling point. $\mathrm{F}=$ freezing point, $M=$ melting point $(\mathrm{Mean} \pm$ SD)

\begin{tabular}{|c|c|c|c|c|c|}
\hline Species & $\mathrm{N}$ & $\mathrm{SCP}$ & $F$ & $\mathbf{M}$ & $\mathrm{F}-\mathrm{M}$ \\
\hline \multirow[t]{2}{*}{ E. antarcticus } & $3 a$ & $-11.4 \pm 0.6$ & & & \\
\hline & $3 b$ & & $-1.98 \pm 0.06$ & $-1.95 \pm 0.07$ & $-0.03 \pm 0.09$ \\
\hline \multirow[t]{2}{*}{ E. superba } & $6 a$ & $-9.0 \pm 1.6$ & & & \\
\hline & $4 b$ & & $-2.00=0.09$ & $-1.96 \pm 0.08$ & $-0.04 \pm 0.12$ \\
\hline \multirow[t]{2}{*}{ G. oceanicus } & $4 a$ & $-6.3 \pm 0.3$ & & & \\
\hline & $4 \mathrm{~b}$ & & $-1.13 \pm 0.04$ & $-1.12 \pm 0.03$ & $-0.01 \pm 0.05$ \\
\hline \multirow[t]{2}{*}{ G. wilkirzkii } & $6 a$ & $-3.8 \pm 0.8$ & & & \\
\hline & $5 b$ & & $-1.98 \pm 0.06$ & $-1.95 \pm 0.09$ & $-0.03 \pm 0.11$ \\
\hline A. glacialis & $5 a$ & $-7.8 \pm 1.7$ & & & \\
\hline
\end{tabular}

$a=$ intact animals, $b=$ haemolymph (data from Aarset \& Torres 1989. Aarset \& Zachariassen 1988, Aarset \& Aunaas 1987b) 
Fig. 4. Haemolymph osmolality (A), sodium concentrations (B) and chloride concentrations $(C)$ in the haemolymph of Gammarus wilkitzkii (-) acclimated for 24 hours to various salinities. The data are given as Mean $\pm \mathrm{SD}$ with number of animals indicated above each point. The solid lines show the isosmotic (A) or iso-ionic conditions (B, C) (Aarset \& Aunaas 1987b).

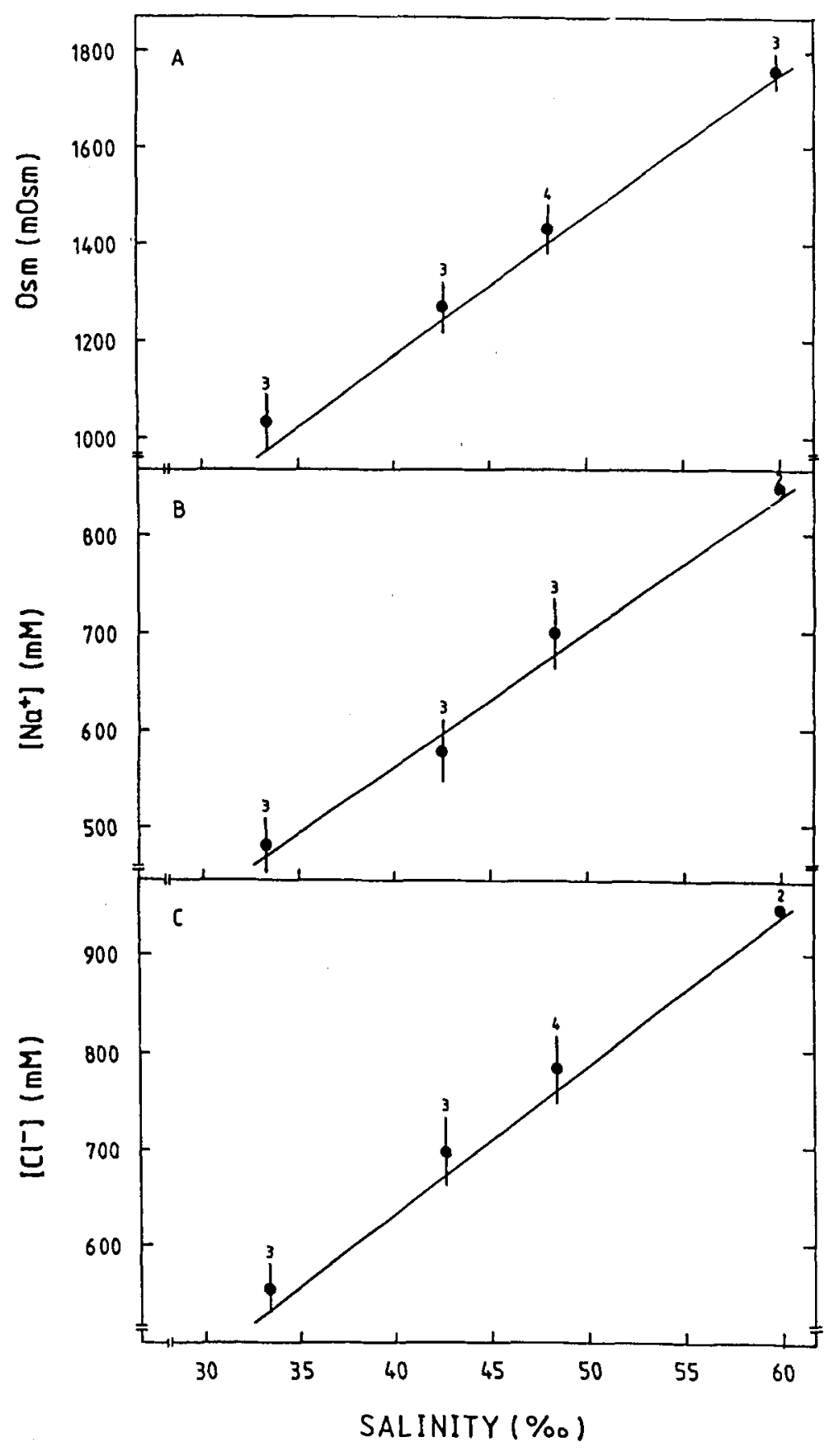

higher temperature than animals cooled in air indicates that other mechanisms than spontaneous internal freezing were causing the injuries.

\section{Brine exposure}

During sea-ice growth, brine is excluded to the sea and thereby increases the salinity of the underice environment (Maykut 1985). When the Arctic 
amphipod G. wilkitzkii was acclimated to high salinity media, the amphipod responded by being an osmoconforming organism in the salinity range of 34 to $60 \%$ (Fig. 4A). The results also indicate a passive relationship between the concentrations of haemolymph and seawater $\mathrm{Na}^{+}$and $\mathrm{Cl}^{-}$(Fig. 4B and C) (Aarset \& Aunaas 1987b). An increased concentration of total FAA in $G$. wilkitzkii versus elevated salinities has been observed. This implies that during sea-ice growth, the amphipods in the vicinity of the ice conform to the ambient brine. Thus, the animals lower the melting point of their body fluids and thereby reduce the probability of a heterogenous ice nucleation. An increased body fluid osmolality would probably also cause a colligative depression of the supercooling point (Zachariassen \& Hammel 1976). This adaptation assumes that the cooling rate of the medium is slow enough to make a gradual increase in the brine osmolality, promoting an osmolality adjustment in the haemolymph of the animals. By direct exposure of G. wilkitzkii to a salinity increase from 34 to $46 \%$, the amphipod become isosmotic in about 3-4 hours, indicating a good possibility of the animals to conform to the brine in due time underneath the Arctic sea ice (Aarset \& Aunaas 1987b).

By acclimating to high salinity media, the Antarctic under-ice crustaceans $E$. antarcticus and $E$. supherba also conformed osmotically to their tolerated salinity range (26 to $45 \%$ ) (Aarset \& Torres 1989), which to some extent corresponds to the studies of the Antarctic amphipod Orchomene plebs (Rakusa-Suszczewski \& McWhinnie 1976). During sea-ice growth, both the krill and the amphipod were similar to the Arctic amphipods, able to stay in the vicinity of the ice by conforming to the ambient brine and thus lowering the melting point of their body fluid. However, a low temperature seems to promote the salt tolerance for both the krill and the amphipods, a mechanism which has previously been documented for other crustaceans (Kinne 1964). The Arctic and the Antarctic sympagic fauna thus seem to be rather alike in their strategy towards freezing.

\section{Metabolic responses versus salinity}

Although the sympagic amphipod species have developed physiological mechanisms to cope with variations in seawater salinity, the environmental osmotic stress could interfere with the metabolism of the organism. Changes in seawater salinity affected the metabolic rates of the sympagic amphipods $G$. wilkitzkii, $O$. glacialis and $A$. glacialis. This may be of ecological significance for the Arctic amphipods.

\section{Time-course of metabolic responses versus low} salinity

The time-courses of specific oxygen consumption and nitrogen excretion rates of $G$. wilkitzkii and O. glacialis, transferred from 35 to $5 \%$ seawater, indicated that the amphipod species elevated both rates just after the transfer and kept them high throughout the experimental period (26-72 hours). Although an increase in the time-course of the $\mathrm{O}: \mathrm{N}$ ratio in $G$. wilkitzkii occurred during the first hours of the hyposmotic stress, the ratio was kept rather constant in both species at about 15-20, reflecting lipid/protein catabolism (Aarset \& Aunaas 1990a, b). These results may indicate that the salinity induced metabolic responses of the Arctic amphipods is slower than previously demonstrated for estuarine crustacean species (Bulnheim 1972; Mangum et al. 1976; Taylor et al. 1987).

\section{Metabolic responses versus salinity acclimation}

Acclimation of the sympagic amphipods $G$. wilkitzkii, $O$. glacialis and $A$. glacialis to low salinities induced elevated oxygen consumption rates for all species (Aarset \& Aunaas 1990a, b, 1992). For both $O$. glacialis and $A$. glacialis the lowest rate was obtained at a salinity of $35 \%$ and the hyposomotic stress induced a 2-3 fold increase in the rate (Aarset \& Aunaas 1990b, 1992). However, the oxygen consumption rate of $G$. wilkitzkii was salinity-independent in the range of 25 to $48 \%$ o (Fig. 5A). Below a salinity of $15-20 \%$ o $G$. wilkitzkii was rather sensitive to salinity stress, with a 2-3 times increase in the oxygen consumption rate when transferred from 35 to $15 \%$. This indicates that the amphipods can live in the sea-ice environment in the fully compensated salinity range with minor changes in energy requirements. In an invironment with salinities below 15-20\%o, the animals will need higher energy inputs. However, the salinity had little effect on the mean oxygen consumption rates of $E$. antarcticus and $E$. superba in their tolerated salinity ranges (Aarset \& Torres 1989). 
Fig. 5. The rates of specific oxygen consumption (A), specific ammonia excretion (B) and O:N ratios (C) of Gammarus wilkitzkii acclimated for 24 hours to various salinities. The data are given as Mean \pm SD with number of animals indicated above each point (Aarset \& Aunaas 1990a).
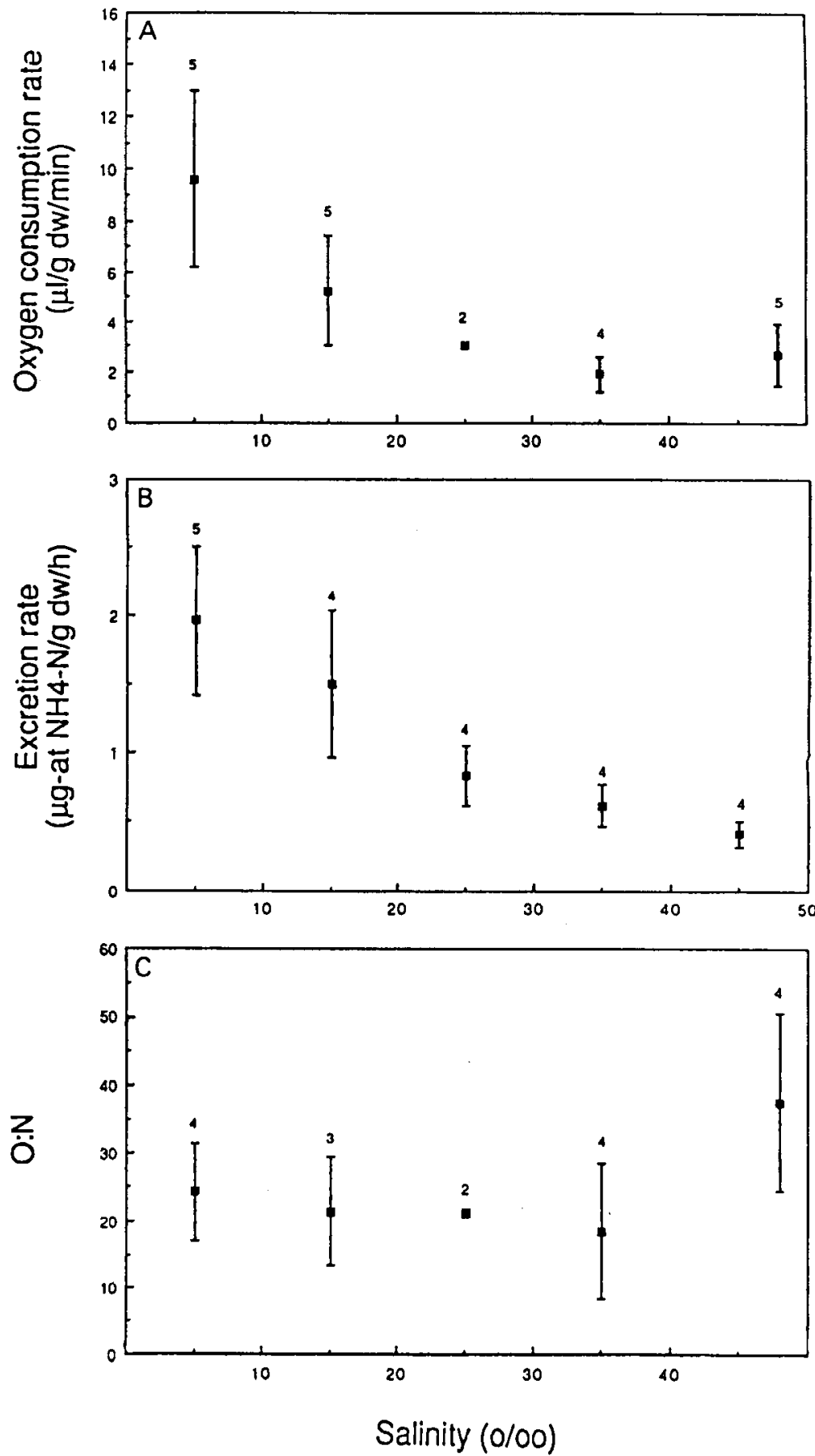

An increased ammonia excretion rate in dilute media was documented for the under-ice amphipods $G$. wilkitzkii, $O$. glacialis and $A$. glacialis. This has previously been noted in a number of other crustacean species (Reginault 1984; Taylor et al. 1987; Haberfield et al. 1975; Spaargaren et al. 1982; Harris \& Andrews 1985; Aarset \& Aunaas $1990 \mathrm{a}, \mathrm{b}, 1992)$. Exposure of $G$. wil- 
kitzkii to the 24 hour hyposmotic stress resulted in a substantial increase in ammonia excretion rates in individuals exposed to salinities below 25\% (Fig. 5B). Thus, the excretion rate to some extent seems to correspond with the changes in the oxygen consumption rate. In the salinity range of $25-48 \%$, there was a small decrease in excretion rate, indicating that the amphipods were not fully compensating for the salinity variations in the media. Exposure to salinities below 15-20\%o revealed sensitivity to the salinity stress with a 2-3 times increase in the excretion rate. This observation and the concomitant elevation of the oxygen consumption rates might support an energetically favourable migration of the animals into waters of higher salinities.

Changes in the energy substrate utilisation as a function of osmotic stress has been observed in some crustaceans (Tendengran et al. 1988; Stern et al. 1984); however, a rather constant $O: N$ ratio of about 15-20 has been documented for the sympagic amphipods $O$. glacialis and $A$. glacialis (Aarset \& Aunaas 1990b, 1992). In G. wilkitzkii the pooled $\mathrm{O}: \mathrm{N}$ ratio for 24 hours osmotic stress varied from 21 at hyposmotic to 37 at hyperosmotic stress (Fig. 5C); however, individual variations in the ratios displayed no significant differences. Ikeda \& Bruce (1986) pooled the data for 12 Antarctic zooplankton species and obtained an $\mathrm{O}: \mathrm{N}$ ratio of about 14 . Antarctic krill E. superba ranged from 21 to 50 (Hirche 1983).

\section{Metabolic responses versus osmolality differences - haemolyph sodium concentrations}

In many crustaceans the respiratory rate has been demonstrated to be highest when the osmotic difference between haemolymph and external medium is at a maximum (Rao 1985; King 1965; Hagermann 1970). The lowest respiratory rate occurred when the osmotic difference between haemolymph and medium was minimal. The observations were supported by the studies of $G$. wilkitzkii (Fig. 6A) and $O$. glacialis (Aarset \& Aunaas $1990 \mathrm{a}, \mathrm{b}$ ). These amphipods were osmoregulators at low salinities, maintaining elevated haemolymph concentrations of $\mathrm{Na}^{+}$and $\mathrm{Cl}^{-}$ (Aarset \& Aunaas 1987a). The observed increase in the oxygen consumption rates thus seems to indicate increased energy requirement for osmotic regulation at low salinities. However, the energy actually required for osmo- and ionicregulation in crustacean species, calculated from thermodynamic considerations, has been claimed to account for only a minor part $(1-5 \%)$ of the observed increase in the oxygen consumption rate (Potts 1955; Styczynsaka-Jurewicz 1970; Spaargaren 1975; Dalla Via 1987). Another reason for the accelerated respiratory rates may be related to the catabolism of free amino acids during cell volume regulation, as the control of the amino acid pool is governed mostly by changes in transport activity, deamination, and oxidation of the acids to $\mathrm{CO}_{2}$ (Gilles 1973).

Mangum et al. (1976) demonstrated that ammonia excretion of the crab Callinectes sapidus was related to the osmotic difference between blood and water. These observations were supported by the excretion rate of both $G$. wilkitzkii (Fig. 6B) and $O$. glacialis (Aarset \& Aunaas $1990 \mathrm{a}, \mathrm{b})$. The main site of ammonia transfer in crustaceans appears to be the gill epithelium (Evans \& Cameron 1986), where the $\mathrm{NH}_{4}^{+}$ion has been proposed to act as a counter ion in the regulation of haemolymph sodium concentrations (Weiland \& Mangum 1975; Kirschner 1979; Taylor et al. 1987). Thus, a minor decrease in haemolymph sodium would coincide with increased ammonium output during hyposmotic stress. In $G$. wilkitzkii the time-course of the haemolymph sodium concentration might support this observation.

In several crustacean species, the rate of ammonia excretion may be reduced during long term exposure to hyperosmotic stress (Needham 1957; Mangum et al. 1976). In G. wilkitzkii there was a decrease in the excretion rate of individuals exposed to salinities from 25 to $48 \%$ indicating a metabolic requirement of the $\mathrm{NH}_{4}^{+}$ion at higher salinities. Armstrong et al. (1981) suggested a reversal of the $\mathrm{Na}^{+} / \mathrm{NH}_{4}^{+}$exchange mechanism in the prawn Macrobrancium rosenbergii, allowing the animals to hyporegulate in concentrated media. However, no ability to hyporegulate has yet been demonstrated in $G$. wilkitzkii (Aarset \& Aunaas 1987b). Hyporegulation would raise the melting point of the amphipod haemolymph, and under such circumstances ice nucleation would be likely to occur at low temperatures.

\section{Metabolic responses versus temperature}

Crustaceans which have adapted to the low temperatures of the Antractic oceans seem to be 

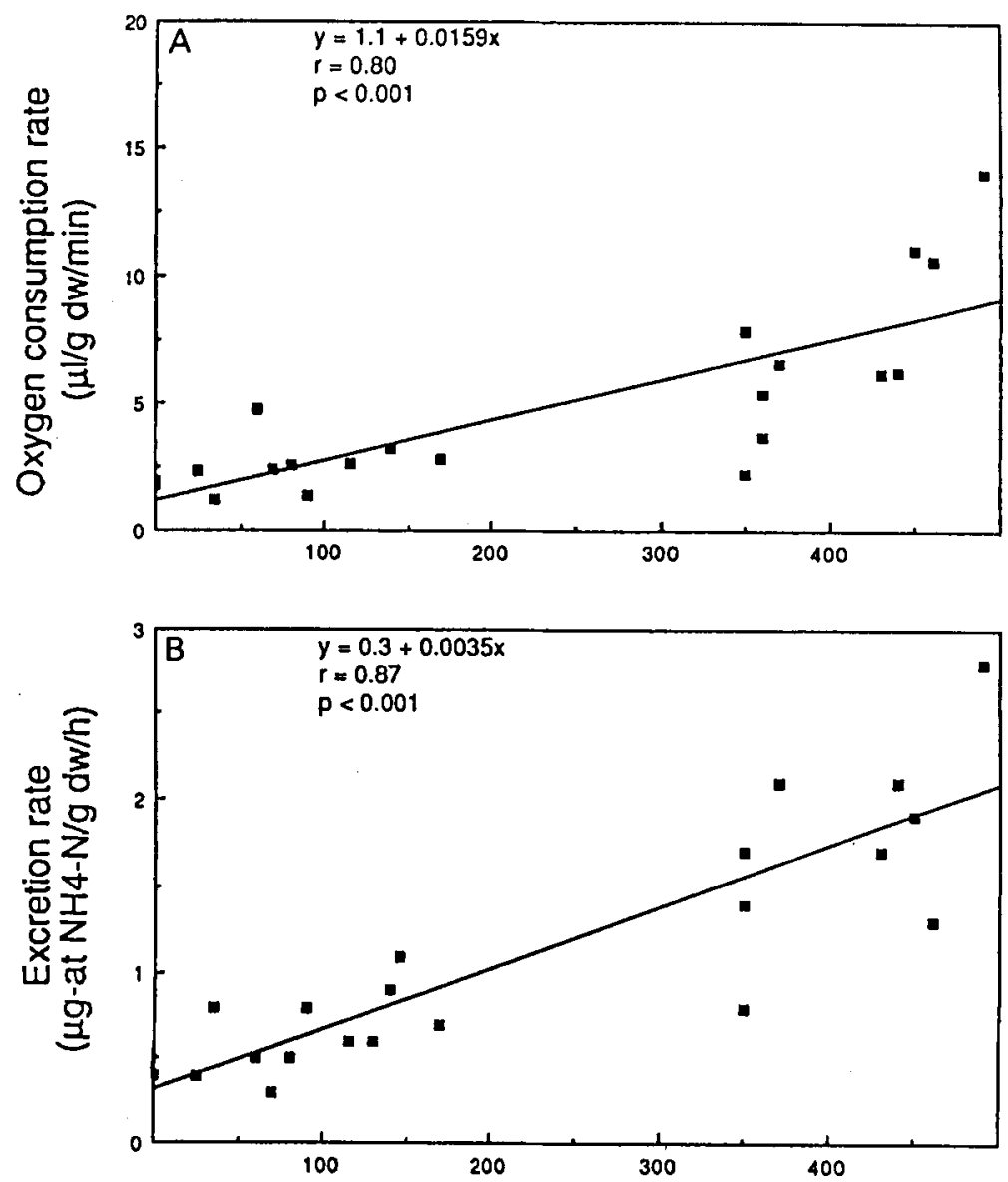

Fig. 6. The rates of specific oxygen consumption (A), specific ammonia excretion (B) and $\mathrm{O}: \mathrm{N}$ ratios (C) of Gammarus wilkitzkii as a function of the osmotic difference between the heamolymph and medium osmolality. The simple regressions are indicated by solid lines (Aarset \& Aunaas 1990a).

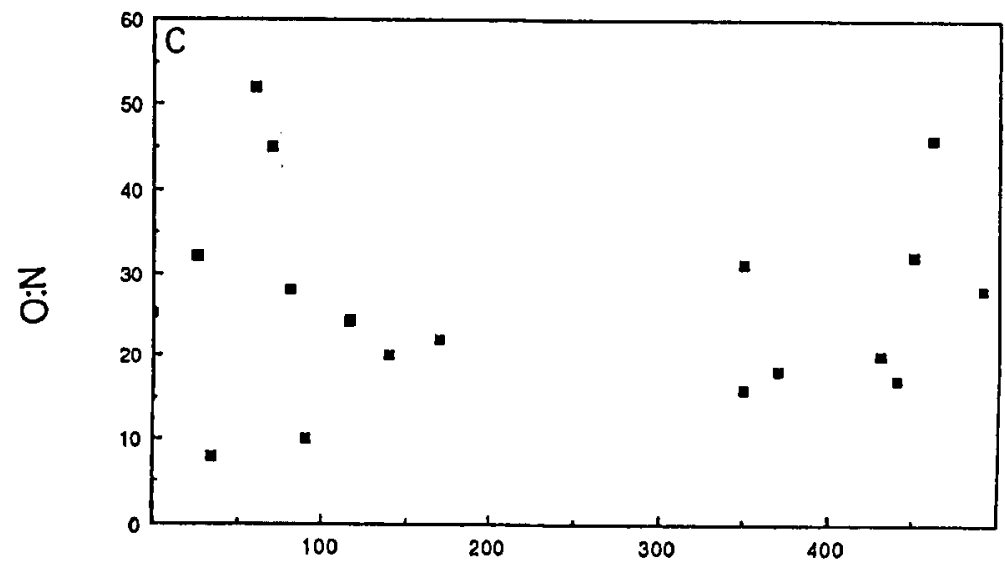

Osmolality haemolymph-medium (mOsm) 
sensitive to elevated ambient temperatures (Rakusa-Suszczewski 1980, 1982; Rakusa-Suszczewski \& Klekowksi 1973). However, Scholander et al. (1953) and Percy (1975) indicated that most of the Canadian Arctic crustaceans they studied survived a temperature exposure of about $18^{\circ} \mathrm{C}$. In our studies of $G$. wilkitzkii, $O$. glacialis and $A$. glacialis, short term temperature exposures from $-1^{\circ}$ to $10^{\circ} \mathrm{C}$ were not lethal to the under-ice amphipods, although the maximal annual variation in temperature of the surface waters of the Arctic Barents Sea is about $3-4^{\circ} \mathrm{C}$. As the crustaceans are unable to control their body temperature, their metabolic rates should vary with changes in ambient temperatures. The general response to increasing temperature is an increased metabolic rate, although several crustacean species appear to be thermally insensitive (low $Q_{10}$ values) over wide temperature ranges (Prosser 1973; Vernberg 1983).

\section{Oxygen consumption}

Percy (1975) reported that the oxygen consumption rate of the winter acclimated individuals of the benthic amphipod Onisimus affinis were relatively temperature-insensitive between $0^{\circ}$ and $8^{\circ} \mathrm{C}$ with a $\mathrm{Q}_{10}$ of 1.36 . However, above $8^{\circ}$ the rate increased rapidly with temperature as indicated by a $\mathrm{Q}_{10}$ of 2.4 between $8^{\circ}$ and $15^{\circ} \mathrm{C}$. Similar results have been demonstrated for the Arctic copepod Calanus glacialis (Tande 1988) and the Antarctic krill Euphausia superba (McWhinnie 1964). The effect of elevated temperatures on the metabolic rates of the Arctic under-ice amphipods $G$. wilkitzkii, $O$. glacialis and $A$. glacialis revealed an overall increase-response for all species (Aarset \& Aunaas 1990c, d). Although the rate of $A$. glacialis appeared to be independent at temperatures between $0^{\circ}$ and $5^{\circ} \mathrm{C}$, with a rather low $Q_{10}$ value, the rate increased significantly as the temperature increased further from $5^{\circ}$ to $10^{\circ} \mathrm{C}$ (Fig. 7A). The first response may thus indicate a conservation of energy at low temperatures.

Both $G$. wilkitzkii and $O$. glacialis exhibited "normal" $\mathrm{Q}_{10}$ values of 3.4 and 3.6, respectively, in the temperature range $0^{\circ}$ to $10^{\circ} \mathrm{C}$. In the range from $0^{\circ}$ to $5^{\circ} \mathrm{C}$, which is approximately the range these amphipods generally would experience in the Arctic, both species displayed rather high $Q_{10}$ values, with the most pronounced increased by O. glacialis (Aarset \& Aunaas 1990b). High $\mathrm{Q}_{10}$ values have been documented for several polar species as an indication of sensitivity to temperature changes (Klekowski et al. 1973). However, Scholander et al. (1953) discussed the problems by using $Q_{10}$ as an indicator of adaptation to the environment. They concluded that physiological adaptation of poikilotherms to cold was reflected in the lateral displacement of the metabolism temperature curve. Wohlschlag (1960) supported this theory, but arguments against the concept of metabolic cold adaptation have also been presented (Clarke 1980, 1983; Maxwell \& Ralph 1985). However, the metabolism temperature curve may vary according to season, starvation, sex, and activity of the animals (Vernberg 1983; Clarke 1980), making comparative data difficult to interpret.

\section{Ammonia excretion}

The rate of ammonia excretion represents a rate at which metabolic systems are digesting, assimilating and processing nitrogen substances. An increase in the excretion rate with increasing temperatures therefore suggests an increase in the digestion and assimilation efficiencies at higher temperatures. Several crustacean species, such as the spot prawn Pandalus platyceros and the Antarctic isopod Glyptonotus antarcticus (White 1975), do increase the excretion rate with temperature. However, excretion rates of copepodite stage $\mathrm{V}$ as well as adult females of the Arctic copepode Calanus glacialis were temperature independent in the range of $-1.7^{\circ}$ to $1^{\circ} \mathrm{C}$ (Tande 1988).

The effect of elevated temperature on the excretion rate of the under-ice amphipod $A . g$ lacialis revealed a significant increase in the rate at both $0^{\circ}, 5^{\circ}$ and $10^{\circ} \mathrm{C}$ with an overall $\mathrm{Q}_{10}$ of 1.8 (Fig. 7B). The results reveal a significant increase in the nitrogen excretion rates for both $G$. wilkitzkii and $O$. glacialis by an elevation of temperature from $0^{\circ}$ to $10^{\circ} \mathrm{C}$, with an overall $Q_{10}$ of 1.9 and 2.3 respectively (Aarset \& Aunaas 1990c). In the temperature range from $0^{\circ}$ to $5^{\circ} \mathrm{C}$ the most pronounced effect, as for the oxygen consumption rate, occurred in $O$. glacialis. Thus, the ammonia excretion rates indicated an increased $\mathrm{N}$-loss to the environment during the high temperature exposure. However, as the Arctic poikilotherms usually are subjected to only minor variations in sea surface temperature, the observed $\mathrm{N}$-loss to the Arctic polar ocean would be significantly lower. 
Fig. 7. The rates of log specific oxygen consumption (A), specific ammonia excretion (B) and $\mathrm{O}: \mathrm{N}$ ratios (C) of Apherusa glacialis at a salinity of $35 \mathrm{ppt}$, after an acute exposure to

temperatures of $0^{\circ}, 5^{\circ}$ and $10^{\circ} \mathrm{C}$. The simple regressions are represented by solid lines enclosed by $95 \%$ confidence limits. Each point represents one animal (Aarset \& Aunaas 1992).
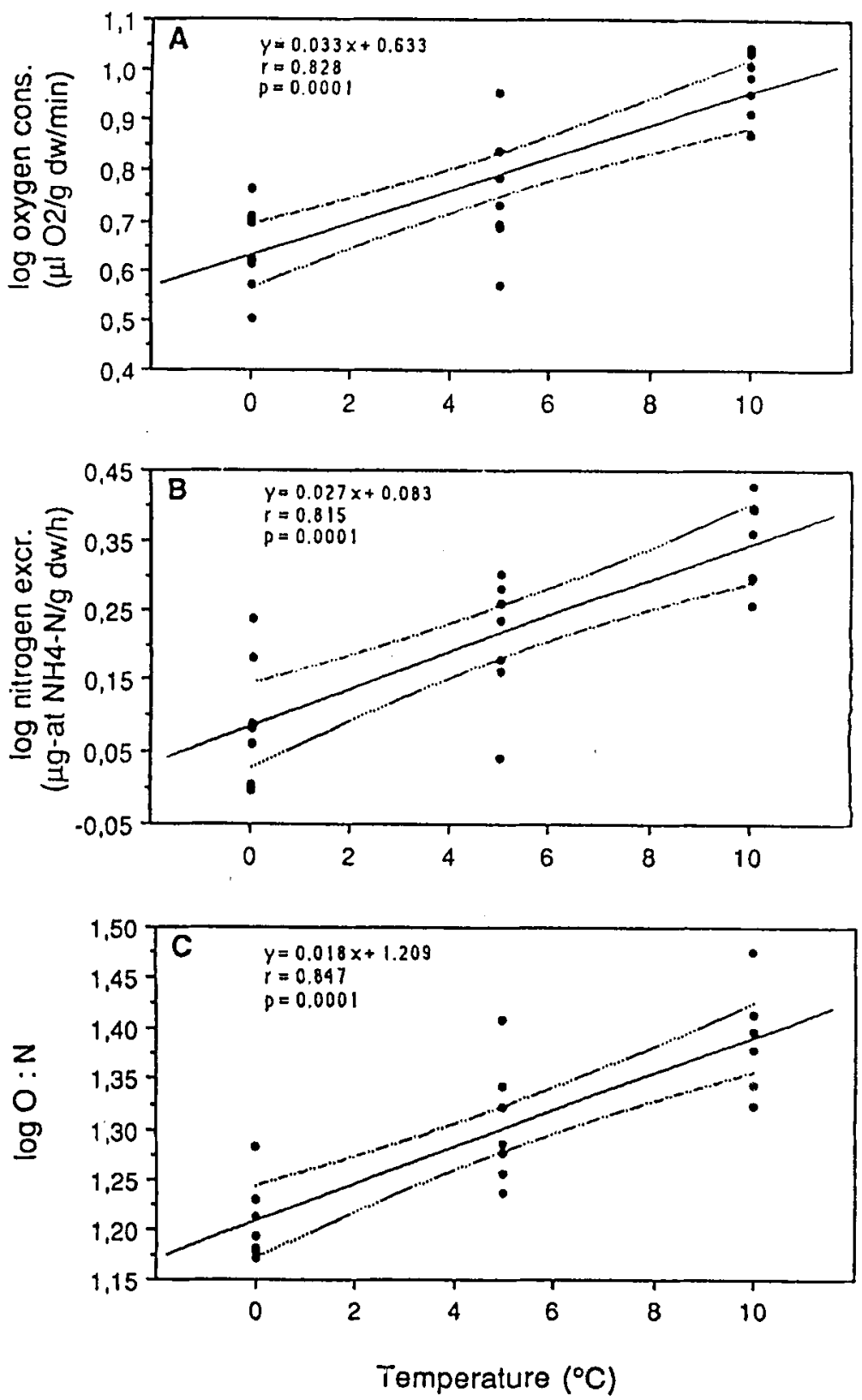

\section{$O: N$}

The $\mathrm{O}: \mathrm{N}$ atomic ratio reflects the overall balance of the amphipod metabolism, related to internal energy requirements and external variables. It seems to be sensitive to the nutritious status of the animals, to the season, and to some extent the temperature (Mayzaud \& Conover 1988). Ikeda
(1974) demonstrated an $\mathrm{O}: \mathrm{N}$ ratio of warm water species to be lower than cold water species. The copepod Acartia clausi and the krill Meganyctiphanes norvegica exhibited opposite response to increasing temperature (Conover \& Mayzaud 1976) while White (1975) found a bimodal distribution for the Antarctic isopod Glyptonotus 
antarcticus. The sympagic amphipod Apherusa glacialis demonstrated an increase in the $\mathrm{O}: \mathrm{N}$ ratio with temperature elevation (Fig. $7 \mathrm{C}$ ) and similar observations have been obtained for $G$. wilkitzkii and $O$. glacialis with overall $\mathrm{Q}_{10}$ values of 2.0 and 1.6 respectively (Aarset \& Aunaas 1990c). This indicates a temperature induced change in the metabolic substrate for all species towards lipids. However, in the temperature range from $0^{\circ}$ to $5^{\circ} \mathrm{C}$ the most pronounced increase occurred in G. wilkitzkii. In conclusion, the oxygen consumption rates for all species seem to be more sensitive to acute temperature exposure than the nitrogen excretion rates, which might represent a general trend in Arctic amphipod metabolism.

Acknowledgements. - This work is part of the Pro Mare programme and has been financed by the Norwegian Research Council for Science and Humanities (NAVF). The author would like to thank K. E. Zachariassen for reading the manuscript.

\section{References}

Aarsct. A. V. 1982: Freezing tolerance in intertidal invertebrates (a review). Comp. Biochem. Physiol. 73A. 571-580.

Aarset, A. V. 1988: Under-ice fauna from the Weddell Sea: Responses to low temperature and osmotic stress. Antarctic J. US 22, 170-171

Aarset, A. V. \& Aunaas, T. 1987a: Osmotic responses to hyposmotic stress in the amphipods Gammarus wilkitzkii, Onisimus glacialis and Parathemisto libellula from Arctic waters. Polar Biol. 7. 189-193.

Aarset, A. V. \& Aunaas. T. 1987b: Physiological adaptations to low temperature and brine exposure in the circumpolar amphipod Gammarus wilkitzkii. Polar Biol 8, 129-133.

Aarset, A. V.\& Aunaas, T. 1990a: Effects of osmotic stress on oxygen consumption and ammonia excretion of the Arctic sympagic amphipod Gammarus wilkizkii. Mar. Ecol Prog. Ser. 58, 217-224.

Aarset, A. V. \& Aunaas. T. $1990 \mathrm{~b}$ : The influence of environmental salinity on oxygen consumption and ammonia excretion of the under-ice amphipod Onisimus glacialis. Mar. Biol. 107, 9-15

Aarset, A. V. \& Aunaas, T. 1990k: Metabolic responses of the sympagic amphipods Gammarus wilkitzkii and Onisimus glacialis to acute temperature variations. Mar. Biol. 107.433438.

Aarset. A. V. \& Aunaas. T. 1992: Metabolic responses of acute temperature and osmotic stress of the Arctic under-ice amphipod Apheriusa glacialis. Polar Biol. In press.

Aarset, A. V. \& Torres, J. J. 1989: Cold resistance and metabolic responses to salinity variations in the amphipod Eusirus aniarcticus and the krill Eupausia superba. Polar Biol . 9. 491497.

Aarset, A. V. \& Jørgensen. L. 1988: Cold hardiness of the cggs of the plaice. Pleuronectes platessa. Polar Biol. 9. 95-99.

Aarset. A. V. \& Zachariassen. K. E. 1988: Low temperature tolerance and osmotic regulation of the amphipod Gammarus oceanicus from Spitsbergen waters. Polar Res.6, 35-41.

Allen. J. A. \& Garrett. M. R. 1971: Taurine in marine invertebrates. Adv. Mar. Biol. 9. 205-253.

Andreas. E. L. \& Ackley. S. F. 1982: On the differences in ablation seasons on the Arctic and Antarctic sea ice. J. Atmos. Sci. 39, 440-447.

Armstrong, D. A., Strange, K., Crowe, J., Knight, A. \& Simmons. M. 1981: High salinity acclimation by the prawn Macrobrachium rosenbergii: Uptake of exogenous ammonia and changes in endogenous nitrogen compounds. Biol. Bull. Mar. Biol. Lab., Woods Hole 160, 349-365.

Bulnheim, H. P. 1972: Vergleichende Untersuchungen zur Atmungsphysiologie euryhaliner Gammariden unter besonderer Berucksichtigung der Salzgehaltsanpassung. Helgolander Wiss. Meeresunters. 23, 485-534.

Carey. A. G., Jr. 1985: Marine Ice Fauna: Arctic. Pp. 173-190 in Horner. R. A. (ed.): Sea lce Biota. CRC Press. Florida.

Clarke. A. 1980: A reappraisal of the concept of metabolic cold adaptation in polar marine invertebrates. Pp. 77-92 in Bonner. W. N. \& Berry, R. J. (eds.): Ecology in the Antarctic. Academic Press, London.

Clarke. A. 1983: Life in cold water: The physiological ecology of polar marine ectotherms. Oceanogr. Mar. Biol. Ann. Rev. 2I, 341-453.

Clarke. M. E. 1985: The osmotic role of amino acids: Discovery and function. Pp. 412-423 in Gilles, R. \& Gilles-Baillien, $\mathrm{M}$. (eds.): Transport processes, iono- and osmoregulation. Springer Verlag. Berlin.

Claybrook, D. L. 1983: Nitrogen metabolism. Pp. 163-213 in Mantel, L. H. (ed.) The biology of crustacea. Internal anatomy and physiological regulation. Vol 5. Academic Press, New York.

Cross, W. 1982: Under ice biota at the Pond Indlet ice edge and in adjacent fast ice areas during spring. Arctic 35, 13-27.

Conover. R. J. \& Corner. E. D. S. 1968: Respiration and nitrogen excretion by some marine zooplankton in relation to their life cycles. J. Mar. Biol. Ass. U.K. 48, 49-75.

Conover, R. J. \& Mayzaud, P. 1976: Respiration and nitrogen excretion neritic zooplankton in relation to potential food supply. Pp. 151-163 in Persoone, G. \& Jaspers, E. (cd.): Proc. 10th Europ. Mar. Biol. Symp. Ostend, Belgium, Vol 2. Univers. Press, Wetteren.

Cox. G. F. N. \& Weeks. W. F. 1974: Salinity variations in sea ice. J. Glaciol. 67, 109-120.

Dalla Via. G. J. 1986: Salinity responses of the juvenile penaeid shrimp Penaeusjaponicus. Free amino acids. Aquaculture 55 , 307-316.

Dalla Via, G. J. 1987: Effects of salinity and temperature on oxygen consumption in a freshwater population of Palaemonetes antennarius (Crustacea. Decapoda). Comp. Biochem. Physiol. 88A, 299-305.

Denstad, J. P.. Aunaas, T. Børseth, J. F., Aarset, A. V. \& Zachariassen, K. E. 1987: Thermal hyteresis antifreeze agents in fishes from Spitzbergen waters. Polar Res. 5, 171-174.

DeVries. A. L. 1971: Glycoproteins as biological antifreeze agents in the Antarctic fishes. Science 172, 1152-1155.

Dorgelo. J. 1977: Comparative ecophysiology of gammarids (Crustacea: Amphipoda) from marine, brachish- and freshwater habitats exposed to the influence of salinity-temperature combinations. IV. Blood serum regulation. Neth. J. Sea. Res. 11, 184-199.

Eide, L. \& Martin, S. 1975: The formation of brine drainage features in young sea ice. J. Glaciol. 14, 137-154. 
Evans, D. H. \& Cameron, J. N. 1986: Gill Ammonia Transport. J. Exp. Zool. 239. 17-23.

Florkin, M. \& Schoffeniels, E. 1969: Molecular approaches to ecology. Academic Press, NY.

Gilles, R. 1973: Oxygen consumption as related to the aminoacid metabolism during osmoregulation in the blue crab $\mathrm{Cal}$ linectes sapidus. Neth. J. Sea Res. 7, 200-207.

Gilles, R. 1979: Mechanisms of osmoregulation in animals. Wiley \& Chichester UK.

Gilles, R. \& Pequeux, A. 1983: Interactions of chemical and osmotic regulation with the environment. Pp. 109-177 in Vernberg, J. F. \& Vernberg, W. B. (eds.): The Biology of Crustacea, Vol. 8, Academic Press, NY.

Gordon, A. L. 1981: Seasonality of Southern Ocean Sea ice. J. Geophys. Res. 86, 4193-4197.

Green, J. M. \& Steele, P. 1975: Observation of marine life beneath sea ice, Resolute Bay, NWT. Proc. Cicum Conf Nothern Ecol 2, 77.

Gulliksen, B. 1984: Under-ice fauna from Svalbard waters. Sarsia $69,17-23$.

Gulliksen, B. \& Lønne, O. J. 1989: Distribution, abundance and ecological importance of marine sympagic fauna in the Arctic. Rapp. P.-v. Réun. Cons. Int. Explor. Mer 188, 133138.

Haberfield, E. C., Haas, L. W. \& Hammen, C. S. 1975: Early ammonia release by a polychaete Nereis virens and a crab Carcinus maenas in diluted sea water. Comp. Biochem. Phys. iol. 52, 501-503.

Hagerman, L. 1970: The oxygen consumption of Crangon vulgaris (Fabricius) (Crustacea, Natantia) in relation to salinity. Ophelia 7, 283-292.

Harris, R. R. \& Andrews, M. B. 1985: Total NPS pool and ammonia net efflux rate changes in Carcinus maenas during acclimation to low environmental salinity. Comp. Biochem. Physiol. 82A, 301-308.

Hirche, H. J. 1983: Excretion and respiration of the Antarctic krill Euphausia superba. Polar. Biol. 1, 205-209.

Horner, R. A. (ed.) 1985: Sea Ice Biota. CRC Press, Boca Raton, Florida. 215 pp.

Huxtable, R. \& Barbeau, A. 1976: Taurine. Raven Press, NY. $398 \mathrm{pp}$.

Ikeda, T. \& Bruce, B. 1986: Metabolic activity and elemental composition of krill and other zooplankton from Prydz Bay, Antarctica, during early summer (November-December). Mar. Biol. 92, 545-555.

Ikeda, T. 1974: Nutritional ecology of marine zooplankton. Mem. Fac. Fish. Hokkaido Univ. 22, 1-97.

Ivleva, I. V. 1980: The dependence of crustacean respiration rate on body mass and habitat temperature. Int. Rev. Ges. Hydrobiol. $65,1-47$.

King. E. N. 1965: The oxygen consumption of intact crabs and excised gills as a function of decreased salinity. Comp. Biochem. Physiol. I5, 93-102.

Kirschner, L. B. 1979: Control of the extracellular fluid osmolarity, control mechanisms in crustaceans and fishes. Pp. 157222 in Gilles, R. (ed.): Mechanisms of Osmoregulation in Animals. Wiley, New York.

Kinne, O. 1964: The effects of temperature and salinity on marine and brackish water animals. 2. Salinity and temperature-salinity combinations. Oceanogr. Mar. Biol. Ann. Rev. 2, 281-339.

Kinne, O. 1970: Temperature. Pp. 407-512 in Kinne, O. (ed.): Marine Ecology. Environmental factors, Vol 1 . Wiley-Interscience, London.
Kinne, O. 1971: Salinity. Pp. 821-996 in Kinne, O. (ed.): Marine Ecology. Environmental factors, vol 1, Wiley-Interscience, London.

Klekowski, R. Z., Opalinski, K. W. \& Rakusa-Suszczewski, S. 1973: Respiration of Antarctic amphipoda Paramoera walkeri Stebbing during the winter season. Pol. Arch. Hydrobiol. 20 , 301-308.

Lake, R. A. \& Lewis, E. L. 1970: Salt rejection by sea ice during growth. J. Geophys. Res. 75, 583-590.

Lockwood, A. P. M., Inmann. C. B. E. \& Courtney. T. H. 1973: The influence of environmental salinity on the water fluxes of the amphipod crustacean Gammarus duebeni. $J$. Exp. Biol. 58, 137-148.

Malmgren, F. 1927: On the properties of sea-ice. Pp. 1-67 in Sverdrup, H. V. (ed.): The Norwegian North Polar Expedition with the "Maud" 1918-1925 Scientific Results, Vol. I, No. 5.

Mangum, C. P., Silverthorn, S. U., Harris, J. L., Towle, D. W. \& Krall, A. R. 1976: The relationship between blood pH, ammonia excretion and adaptation to low salinity in the blue crab Callinectes sapidus. J. Exp. Zool. 195, 129-136.

Mantel, L. H. \& Farmer, L. L. 1983: Osmotic and ionic regulation. Pp. 53-161 in Mantel, L. L. (ed.): The Biology of Crustacea. Internal Anatomy and Physiological Regulation, Vol. 5. Academic Press, NY.

Maykut, G. A. 1985: The Ice Environment. Pp. 21-82 in Horner, R. A. (ed.): Sea Ice Biota. CRC Press, Boca Raton, Florida.

Mayzaud. P. 1973: Respiration and Nitrogen Excretion of Zooplankton. II Studies of Metabolic Characteristics of starved animals. Mar. Biol. 21, 19-28.

Mayzaud. P. \& Conover, R. J. 1988: O:N atomic ratio as a tool to describe zooplankton metabolism. Mar. Ecol. Prog. Ser. 45, 289-302.

Maxwell. J. G. H. \& Ralph, R. 1985: Non-cold adapted metabolism in the decapod Chorismus antarcticus and other subAntarctic marine crustacean. Pp. 397-406 in Siegfried, W. R., Condy, P. R. \& Laws, R. M. (eds.): Antarctic nutrient cycles and food webs. Springer Verlag, Berlin.

McCoid, V., Miget, R. \& Finne, G. 1984: Effect of environmental salinity of the free amino acid composition and concentration in penaeid shrimp. J. Food Sci. 49, 327-300.

McWhinnie, M. A. 1964: Temperature responses and tissue respiration in Antarctic crustacean with particular reference to krill Euphausia superba. Ant. Res. Ser. 1, 63-72.

Murphy, D. J. 1983: Freezing resistance in intertidal invertebrates. Ann. Rev. Physiol. 45, 289-299.

Nansen. F. 1906: Protozoa from the Ice-Floes of the North Polar Sea. Pp. 1-22 in Nansen, F. (ed.): The Norwegian North Polar Expedition 1893-1896 Scientific Results, Vol. 5, No. 16.

Needham, A. E. 1957: Factors effecting nitrogen excretion in Carcinus maenas (Pennant). Physiologia comp. Oecol. 4, 209-239.

Newbury, T. K. 1983: Under landfast ice. Arctic 36, 328-340.

Niedrauer, T. M. \& Martin, S. 1979: An experimental study of brine drainage and convection in young seas ice. J. Geophys. Res. 84, 1176-1186.

Percy, J. A. 1975: Ecological physiology of Arctic marine invertebrates. Temperature and salinity relationships of the amphipod Onisimus affinis H. J. Hansen. J. Exp. Mar. Biol. Ecol. 20. 99-117.

Potts, W. T. W. 1955: The energetics of osmotic regulation in brackish and fresh-water animals. J. Exp. Biol. 31, 618-630. 
Prosser, C. L. 1973: Comparative animal physiology. W. B. Saunders. Philadelphia

Quarmby, L. M. 1985: The influence of temperature and salinity on the nitrogen excretion of the spot prawn. Pandalus platyceros Brandt. J. Exp. Mar. Biol. Ecol. 87, 229-239.

Rao, K. P. 1958: Oxygen consumption as a function of size and salinity in Metapenae us monoceros Fab. from marine and brackish-water environments. J. Exp. Biol. 35, 307-313

Rakusa-Suszczewski. S. 1980: Hypostenothermic organisms. Pol. Polar Res. 4, 231-241

Rakusa-Suszczewski, S. 1982: The biology and metabolism of Orchomene plebs (Hurley 1965) (Amphipoda: Gammaridea) from McMurdo Sound, Ross sea, Antarctica. Polar Biol. 1, 47-54.

Rakusa-Suszczewski. S. \& Klekowski. R. Z. 1973: Biology and respiration of the antarctic amphipoda (Paramoera walkeri Stebbing) in the summer. Pol. Arch. Hydrobiol. 20, 475-488.

Rakusa-Suszczewski. S. \& McWhinnie M. A. 1976: Resistance to freezing by Antarctic fauna: supercooling and osmoregulation. Comp. Biochem. Physiol. 54A, 291-300.

Reginault, M. 1984: Salinity-induced changes in ammonia excretion rate of the shrimp Crangon crangon over a winter tidal cycle. Mar. Ecol. Prog. Ser. 20, 119-125.

Schoffeniels, E. 1976: Adaptation with respect to salinity. Biochem. Soc. Symp. 41, 179-204.

Scholander, P. F., Flagg. W.. Walters, V. \& Irving. L. 1953: Climatic adaptation in Arctic and Tropical poikilotherms Physiol. Zool. 26. 67-92

Shaw, J. \& Sutcliff, D. W. 1961: Studies on sodium balance in Gammarus duebeni. Lil jeborg and G. pulex pulex (L.) J. Exp. Biol. 38. 1-15.

Sømme, L. 1982: Supercooling and winter survival of terrestrial arthropods. Comp. Biochem. Physiol. 73A, 519-543.

Spaargaren, D. H. 1975: Energy relations in the ion regulation in three crustacean species. Comp. Biochem. Physiol. 51 . 543-548.

Spaargaren, D. H., Richard, P. \& Ceccaldi, H. I. 1982: Excretion of nitrogenous products by Penaeus japonicus Bate in relation to environmental osmotic conditions. Comp. Biochem. Physiol. 72A, 673-678.

Stern. S., Borut, A. \& Cohen, D. 1984: The effect of salinity and ion composition on oxygen consumption and nitrogen excretion of Macrobrachium rosenbergii. Comp. Biochem. Physiol. 79A. 271-274.

Storey, K. B. \& Storey, J. M. 1989: Freezing tolerance and freezing avoidance in ectotherms. Pp. 51-82 in Wang. L. C. H. (ed.): Advances in Comparative and Environmental Physiology, Vol 4. Springer Verlag. Berlin.
Styczynska-Jurewicz, E. 1970: Bioenergetics of osmoregulation in aquatic animals. Pol. Arc. Hydrobiol. 1, 295-302.

Tande. K. 1988: The effect of temperature on metabolic rates of different life stages of Calanus glacialis in the Barents sea. Polar Biol. 8. 457-461.

Taylor, A. C., Spicer, J. I. \& Preston, T. 1987: The relationship between osmoregulation and nitrogen metabolism in the intertidal prawn, Palemon elegans (Rathke). Comp. Biochem. Physiol. 88A. 291-298.

Tedengren, M., Arner, M. \& Kautsky, N. 1988: Ecophysiology and stress response of marine and brackish water Gammarus species (Crustacea, Amphipoda) to changes in salinity and exposure to cadmium and diesel-oil. Mar. Ecol. Prog. Ser. 47, $107-116$

Vernberg, F. J. 1983: Respiratory adaptions. Pp. 1-42 in Bliss, E. D. (ed.): The Biology of Crustacea. Environmental Adaptions, Vol 8. Academic Press, New York.

Wakatsuchi, M. \& Ono. N. 1983: Measurements of salinity of brine excluded from growing sea ice. J. Geophys. Res. 88 , 294-295.

Weeks, W. F. 1968: Understanding the variations of the physical properties of sea ice. Symp. Antarct. Ocean, Chile, Scott Pol. Res. Inst., 173-190.

Weiland, A. L. \& Mangum, C. P. 1975: The influence of environmental salinity on hemocyanin function in the blue crab, Callinectes sapidus. J. Exp. Zool. 193, 265-274.

Werntz, H. O. 1963: Osmotic regulation in marine and freshwater Gammarids (Amphipoda). Biol. Bull. 124, 225-239.

White. M. G. 1975: Oxygen consumption and nitrogen excretion by the gigant Antarctic isopod Glyptonotus antarcticus Eights in relation to cold-adapted metabolism in marine polar poikilotherms. Proc. 9th Europ. Mar. Biol. Symp., Aberdeen, 707-724

Wohlschlag, D. E. 1960: Metabolism of an Antarctic fish and the phenomenon of cold adaptation. Ecology 41, 287-292.

Zachariassen, K. E. 1980: The role of polyols and nucleating agents in cold-hardy beetles. J. Comp. Physiol. 140, 227-234.

Zachariassen. K. E. 1985: Physiology of cold tolerance in insects. Physiol. Rev. 65, 799-832.

Zachariassen, K. E. 1989: Thermal adaptation to polar environments. Pp. 23-34 in Mercer. J. (ed.): Thermal Physiology. Excerpta Medica, Oxford.

Zachariassen, K. E. \& Hammel, H. T. 1976: Nucleating agents in the hacmolymph of insects tolerant to freezing. Nature $262,285-287$.

Zachariassen, K. E. \& Husby, J. A. 1982: Antifreeze effects of thermal hysteresis agents protects highly supercooled insects. Nature 298. 865-867. 